\title{
Colonialism as a Blessing in Disguise: A Study of Selected Anglophone African Novels
}

\author{
Echezona Ifejirika (Ph.D) \\ Department of English, Anambra State University, Igbariam
}

\begin{abstract}
Colonialism as a political, historical, economic and literary concept is generally negatively perceived and portrayed in all ramifications. This perception and depiction is not unconnected with its historical and cultural denigration, oppression suppression, economic exploitation and deprivation, literary prejudice and linguistic interference in the former colonies. However, a critical and dispassionate study of some Anglophone African novels reveal that colonialism, in spite of its derogatory perceptions and criticisms by many African intellectuals from all walks of life, possesses some redeeming features and incontrovertible landmark achievements that made it a necessary evil. This study, therefore, highlights the implied and obvious opinions of some notable African novelists, who through their novels, acknowledged that Colonialism was a negative instrument that advertently or inadvertently brought enlightenment, progress and divergent developments to the colonized Africa and her people. In fact, the study shows that Colonialism was a positive evil and a blessing in disguise to Africa and Africans.
\end{abstract}

\section{INTRODUCTION}

Colonialism is directly negatively associated with forceful occupation of a weaker state or country by a stronger and sometimes much more developed state; the imposition of foreign administrative governance on the weaker State; economic exploration and exploitation, political dominance, cultural and linguistic domination and social oppression, and suppression of members of the colonies by the colonizers. It is these negative characteristic features of Colonialism that made it a repulsive political cum cultural phenomenon and a target of severe criticism by politicians, religious leaders, journalists, enlightened academics, especially literary artists, who are no doubt the most sensitive and critical members in a given society.

However, an in depth, critical and objective reading and analysis of some Anglophone novels, especially Chinua Achebe's earlier novels, reveals that the devil is not as black as he is generally painted and that there are two sides to every coin. He, Chinua Achebe, in spite of severe criticisms of the colonial masters in Africa, sees some positive sides of Colonialism. He unpretentiously said so not only in his novels but also in his social comments and literary reviews and essays. Achebe was not alone in presenting some positive sides of Colonialism. Some literary writes such as Ifeanyi Ezeifeh shared this view with him. For instance, Chinua Achebe, in sincere acknowledgement of the positive contributions of Colonialism to Africa opined. In his book: Morning Yet on Creation Day thus:

But the bounties of the Christian God (personified in colonial missionary or evangelism) were not to be taken lightly - education, paid jobs, and many other advantages that nobody in his right senses could underrate. And in fairness we should add that there was more than naked opportunism in the defection of many to the new religion (Christianity). For in some ways and in certain circumstances it stood firmly on the side of humane behaviour. It said, for instance, that twins were not evil and must no longer be abandoned in the forest to die. Think what that would have done for that unhappy woman whose heart torn to shreds at every birth could now hold on precariously to a new hope. (65).

What Chinua Achebe is saying here and which is adequately expressed in his novels: Things Fall Apart and Arrow of God (Novels used for this study) is that Christianity, though an aspect of Colonialism, brought some goodies to the colonized people. He specifically highlighted the stoppage of killing of twins and provision of employment opportunities as advantages of Colonialism. 
In a similar vein, Charles Nnolim, a renowned critic of African literature corroborated Achebe's view, when he noted in a paper entitled: Morning Yet on Criticism Day: The Criticism of African Literature in the Twentieth Century that:

African contact with Europe has not always been an unhappy one. Nigeria under the British imperial hegemony had a mixed blessing. Nigeria became a subject people under colonial rule but she gained a world language that gave us shared heritage with Europe and the rest of the world (1).

Charles Nnolim, in the above excerpt sees the inevitable adoption of the English language as a lingua franca or official language by some of the colonies as one of the greatest benefits of the contact with Europe (through Colonialism) because the language helped to unify the Babel tongues in Nigeria and other Anglophone African countries, thereby making them beneficial members of the Common Wealth of Nations and indeed the world community. This is courtesy of the English languages.

In his own perspective, very much similar to the preceding ones, Simone Gikandi argues, that Colonialism was positively responsible for the revolutionary and evolutionary development of Modern African literature. For example, without the racial prejudices and appalling images of Africa in Eurocentric African novels, masterminded by writers like Joseph Conrad, James Joyce and Graham Green, African novelists such as Chinua Achebe would not have emerged and classical anti-colonial novels such as Things Fall Apart and Arrow of God would not have been written. Similarly, novels such as Peter Abraham's Mine Boy, Alex La, Guma's A Walk in the Night, Ngugi Wa Thiong'os A Grain of Wheat and Althol Fugard's Sizwe Bansi is Dead (a play) would not have been written and read widely. For example, Chinua Achebe shares the above view when he talks of the forces that propelled him to write his early novels.

According to him:

At the university, I read some appalling novels about Africa (including Joyce Cary's $M r$. Johnson) and I decided that the story we had to tell could not be told for us by anyone else, no matter how gifted or well intentioned (70)

And in fulfilling this onerous task he set for himself and others of his kind, he later said, concerning the Eurocentric criticisms of his novels as mere sociological and anthropological collections:

I would be quite satisfied if my novels, (especially the ones I set in the past) did no more than to teach my readers that their past with all its imperfections was not one long night of savagery from which the first European acting on God's behalf delivered them (45).

In the two excerpts above Achebe clearly states that the reading of racially prejudiced novels of Eurocentric novelists fired his enthusiasm to write his early novels as a response to the biased colonial writers works and as a way of teaching his people positive lessons about themselves and their culture. Similarly, Achebe's argument that Colonialism propelled his zeal to write, is corroborated by Simone Gikandi, a renowned critic of African literature, when he argued that colonialism gave vent to the emergence of Modern African literature; a development which he perceived in the positive in these words:

Modern African literature is produced in the crucibles of colonialism. What this means, is that the men and women who founded the tradition of what we now call modern African writing... were without exception, products of the institutions that colonialism had introduced and developed in the continent. What is now considered to be the heart of literary scholarship on the continent could not have acquired its current identity or function; if the traumatic encounter between Africa and Europe had not taken place. Not only were the founders of Modern African literature colonial subjects, but colonialism was also to be the most important and enduring theme in their works (54).

In other words, without colonialism, complacency and idleness would have given birth to literary eclipse and dearth of classical literary works in Africa. That is, colonialism provided the raw materials for African literary writers and critics.

In the subsequent part of this study, references are elaborately made to some selected African novels to substantiate and sustain the argument in this work; that is, that in spite of all the atrocities associated with colonialism, it was a blessing in disguise 


\section{Colonialism as a Positive InStrument: Evidence from African Novels}

In spite of Chinua Achebe's severe criticism of colonial masters and colonialism in his essays, commentaries and early novels such as Things Fall Apart and Arrow of God, he still retained some positive opinions perception and image of the colonialists who came as missionaries, civil administrators, law enforcement agents, sheer adventurers among other functions in the colonies. $\mathrm{He}$ believes that despite their numerous and unforgivable sins against Africa and Africans, the colonialists served as agent of social enlightenment and change, beacons of light and development, bringers of freedom for the oppressed and hope for the hopeless and the disillusioned in the society. This perspective is unpretentiously reflected in the novels used for the study and this view is truly incontrovertible for those who appreciate some good, sometimes embedded in evil.

For instance, in Things Fall Apart Mr. Brown, an Expatriate Colonial master and a missionary, is presented as a man who had respect for the culture of the people and who acted as a true agent of light and development. Mr. Brown engaged the wise elders of Umuofia in a dialogue, discussion and question and answer session in order to learn the people's cultural beliefs.

During the discussion, he came to know, understand and appreciate the fact that the people know and believe in the supreme God. That is the reason the natives have names of God as: Chineke- (the God that creates) Chukwu or chi-ukwu (the supreme God) Olisabinigwe, (the God that lives in heaven while other gods live on earth). With his profound conviction and understanding of the people's culture, he decided to help in further development and enlightenment of the natives through formal education, establishment Christian of religion and the building of hospitals to cater for the head, heart and health of the natives (the three H). The narrator in Things Fall Apart captures the Scenario thus:

In this way, Mr. Brown learnt a good deal about the religion of the clan and he (Mr. Brown) came to the conclusion that a frontal attack on it (the culture of the natives would not succeed. And so he built a school and a little hospital in Umuofia. He went from family to family begging people to send their children to his school, they (the natives) only sent their slaves or sometimes their lazy children, Mr. Brown begged and argued and prophesied. He said that the leaders of the land in the future would be men and women who had learnt to read and write (128).

Chinua Achebe's argument in the excerpt is that in spite of colonialism which the white man brought to Africa and its deadly consequences on the people, one objectively appreciates the white man for bringing the Christian religion whose aim is to bring salvation to the souls of Africans. The Whiteman also built schools to impart literacy on the natives and essentially to prepare them as effective leaders of their country when colonialism must have abtted. The idea of building hospitals was indeed noble because without good health, future leadership and the preparation for the ultimate heavenly journey would be a mirage.

Achebe's conviction in the positive roles of the colonial masters in the colonies was clearly brought to the fore when he says through the narrator that the white man acted as beacons of light and agent of change and development.

The point is put thus:

But apart from the church, the white man had also brought a government. They had built a court where the District Commissioner judged cases in ignorance. He had court messengers who brought men to him for trial. Many of these messengers came from Umuru where they (the white men) had built the centre of their religion and government. The messengers guarded the prison, which was full of men who had offended against the white man's law. Some of these prisoners had thrown away their twins and some had molested the Christians. (123)

From a critical perspective, the idea of the white man bringing government simply implied that they brought law, order, control and discipline to the native communities. With the presence of the white man, people were no longer free to do whatever they wanted. For example, in the above excerpt, the reader learnt that some of the prisoners physically attacked the missionaries while some had the guts to throw away twins which God generously gave them. Their actions were based on superstition and raw ignorance. By implication, these men committed crimes against humanity and must be brought to order to eschew the primitive and Hobbesian law of the survival of the fittest. It is evident from the 
quotation that the three arms of government: the legislative, the executive and the judiciary were all contained in the white man's government except that there was no clear cut separation of powers and checks and balances.

Furthermore, the developmental strides of the colonial masters in the colonies were not limited to the establishment of churches, schools, hospitals, prisons and courts; they also initiated and boosted trade and commerce between the natives and the expatriate merchants. The author acknowledged the economic contributions of the colonialists when he said:

There were many men and women in Umuofia who did not feel as strongly as Okonkwo about the new dispensation. The white man had indeed brought a lunatic religion but he (the white man) had also built a trading store and for the first time palm oil and kernel became things of great price, and much money flowed into Umuofia. And even in the matter of religion, there was a growing feeling that there might be something in it after all, something akin to method in the overwhelming madness. (126)

So, apart from other advantages of the devilish colonialism, economic growth and development was noticed in the colonies, following the efforts and ideas of the colonialists. The natives experienced immense economic boom because the commercial or economic value of palm oil and kernel was raised through the white man's demands for them. This was to the extent that many people not only saw real money other than cowries, but also earned money and used money to their happiness and satisfaction. This was to the credit of the colonial masters. Apart from these, the stoppage of the primitive superstitious killing of twins, the colonialists also restored value, humanity, freedom, life and dignity to a group of people called outcasts (poor, helpless and unfortunate people sacrificed to gods and goddesses for protection). Achebe's eagle eyes picked this liberty thrust to the outcasts when he said:

These outcasts or Osu, seeing that the new religion welcomed twins and such abominations, thought that it was possible that they would also be received. And one Sunday, two of them (OSU) went into the church. There was immediate stir; but so great was the work the new religion had done among the converts that they did not immediately leave the church when the outcasts came in (111).

Though other worshipers did not leave the church, they protested against the acceptance of the outcasts as normal human beings. The protest led a colonial missionary Mr. Kiaga to explain to the congregation that:

Before God, there is no slave or free (111). And indeed, the two outcasts were received and their acceptance into the church fold gave great impetus to many other outcasts to join the Christian religion. In the words of the missionary Mr. Kiaga, "They (the outcasts) need Christ more than you and I so, the unconditional re-absorption of outcasts into the mainstream of the society seemed to be one of the greatest benefits of colonialism apart from the stoppage of the killing of twins (111).

In a similar vein, Chinua Achebe, in Arrow of God perceived the colonialists as peace makers and advocates of law and order in the society. For example, Captain Winterbottom, reported to Mr. Clark, his peace efforts in settling the land case between Okperi and Umuaro people. When Clark, his fellow White man asked questions about local guns in Captain Winterbottom's office, he replied to Clark thus:

Those guns have a long and interesting history. The people of Okperi and their neigbours, Umuaro, are great enemies. A big savage war had broken out between them over a piece of land. This feud was made worse by the fact that Okperi welcomes missionaries and government while Umuaro, on the other hand, has remained backwards. It was only in the last four or five years that any kind of impression has been made there. I think I can say with all modesty that this change came about after I had gathered and publicly destroyed all firearms in the place, except of course, this collection here (37).

From Winterbottom's statement above, a number of deductions in favour of the expatriate colonial administration could be made. First, the man, as civilized person in authority helped to stop the civil strife between Okperi and Umuaro and in the process, restored peace and order in the two warring communities. Second, there is an impression that the white man is a symbol of light and development 
as could be attested to by the fact that Okperi that warmly received white administrators and missionaries, experienced tremendous development whereas Umuaro that refused to admit visitors (the white man) remained backward until they opened their gates to the white man. For instance, Okperi that served as the seat of government experienced developmental strides as the white man built in the town, his administrative headquarters, with schools, churches hospitals and roads which made the obvious difference between Okperi and other towns where the white man had not gone to settle. No wonder, Ezeulu, in spite of his misunderstanding with Mr. Winterbottom who wanted him to be a warrant chief at the expense of his priestly position in Umuaro, still saw something positive in the white man to the extent that he sent his son Oduche to join the white man in his school and religion. Perhaps as a priest, he foresaw the light and progress that would accrue from the white man's presence in Umuaro. No wonder he told his son, Oduche (the seat of wisdom):

The world is changing. I do not like it. But am like the bird, Eneka nti-oba who said that since men have learnt to shoot without missing, he had learnt to fly without perching. I want one of my sons to join these people (colonialists), and be my eye. If there is nothing in it, you will come back. But if there is something there, you will bring my share (4546).

Of course, Ezeulu knew that there would be something in it and that was why he sent his son, Oduche, to join the white man in his school and church. As a priest of Ulu, he possessed the spiritual capacity to look into the seeds of time to predict the future. One of the "things in it", was the white man's road project that was intended to link up the rural areas such as Umuaro to the administrative headquarters in Okperi. The objective was to open direct access for commerce, evangelism and transportation of goods and services (75). Though Captain Winterbottom gave Mr. Wright approval to use free local labour to do the road project, he quickly and tactically added in his approval letter that:

It was the policy of the administration to resort to this method (use of unpaid labour) only in the most exceptional circumstance. The natives cannot be an excerption to the aphorism that the labourer is worthy of his hire (76).

In line with the above developmental strides by the white man, Ezeulu reiterated his implicit and unshakable belief in the colonial masters as a source of a better and brighter future in any community where they settled. His reiteration became expedient when his son Oduche was reluctant and hesitant to obey his father's request for him (Oduche) to join the white man's school and church. This matter is reported thus:

At first, Oduche did not want to go to church. But Ezeulu called him as a man would speak to his best friend and the boy went forth with pride in his heart. He had never heard his father speak to anyone as an equal... The world is like a mask dancing (he told Oduche). If you want to see it well you do not stand in one place. My spirit tells me that those who do not befriend the white man today will be saying had we known tomorrow (45).

There is in Ezeulu's prophetic utterance the view that the white man alone holds the magic wand that would transform the world into a scientific, technological, economic, political and social haven. Here, Ezeulu was not speaking as a mere mortal but as a spirit man.

In addition, the lieutenant Governor's letter to Captain Winterbottom in which he explained the real motive behind the adoption of Indirect Rule in certain parts of Nigeria, especially in Igbo land, gave credence to the good intentions of the colonial masters towards their subject people.

According to the Governor, while the colonial administration endeavoured to purge the native system of its abuses in order to build a higher civilization, there is urgent need to anchor this upon the soundly rooted native stock that had its foundation in the hearts and minds and thoughts of the people. The letter in part says:

To many colonial nations, native administration means government by white men. You are all aware that H.M.G. considers this policy as mistaken. In place of the alternative of governing directly through administrative officers, there is other method of trying while we endeavour to purge the native system of its abuses to build a higher civilization upon soundly rooted native stock that had its foundation in the hearts, minds and therefore on 
which we can more easily build, moulding it and establishing it into lives consonant with modern ideas and higher standards, and yet all the time enlisting the real force, the spirit of the people, instead of killing all that out and trying to start afresh. We must not destroy the African atmosphere, the whole foundation of his race (55-56).

The above excerpt is a clear demonstration of the incidental and accidental positive intentions of the colonial masters and colonialists towards their colonies and the subject people. The contents of the above letter do not sound pretentious.

The essence of the above long excerpt is to demonstrate through the LT. Governor's diction, his respect for and interest in some positive aspects of the people's culture and the need to use such cultural heritages as foundation on which new and modern civilization would be built. For example, such clauses and phrases in the explanatory letter such as; "To build a high civilization upon soundly rooted native stock." "All the time enlisting the real force the spirit of the people instead of killing all that out and trying to start afresh." "We must not destroy the African atmosphere, the African mind, the whole foundation of his race', go a long way to corroborate the novelist's earlier postulations in the novels showing that in spite of all odds, the Expatriates were indeed agents of development and beacons of light. Their overall intentions were not to destroy, exploit and abuse but to build in the words of the LT. Governor, a higher civilization with modern ideas and higher standards. The contents of LT. Governor's explanation on the British purpose of introducing Indirect Rule in the Eastern parts of Nigeria serve as an exonerating testimony for the Expatriates. To this extent, other acts of Expatriates that were injurious and detrimental to the African natives were accidental and incidental and could be forgiven. Therefore, even if the Governor was pretentious in his explanatory note, the genuineness of his motives and good intentions towards the natives were aptly shown by the letter. The above observation is without prejudice to the fact that "Indirect Rule" had its very intractable problems ranging from the exploitation, tyrannical and high-handedness of some warrant chiefs to the collusion of Expatriates with the Chiefs and local interpreters to further exploit the natives (107-109).

In addition to the novelist's positive presentation of Expatriates in his novel, Tony Clark, Captain Winter bottom's assistant, is presented as a good man and a fair-minded administrator. Clark could not find any further justification to continue to detain Ezeulu in Okperi Prisons and he subsequently released him without waiting for any further directive from his superior officer, Captain Winter bottom, who was then admitted in the missionary hospital at Okperi. The novelist positively reports on Clark thus:

But Clark was not the person to lock a man up without fully satisfying his conscience that justice had not only been done but appeared to have been done. What had worried him was thus: if he kept the fellow in jail, what would he say was his offence. What would he put down in the logs, for making an ass of the Administration? For refusing to be a chief? This apparent small point vexed Clark like a fly at siesta (177).

From the above extract, it is clear that among the Expatriates in various capacities, there were some that had human mind and good conscience and such people could really bring development to the people.

Similarly, in the course of reading and analyzing the third novel from Anglophone country selected for the study, it was discovered that Ifeanyi Ezeifeh, the author of the novel; The Y Year of the Locusts, showed that not all Expatriates were racists, exploiters, high-handed and destroyers. On the contrary, some Expatriates possess positive images that presented them as builders instead of destroyers.

For example, Rev. Father McGrace, the missionary in Igwulube, who ought to have been greatly frightened and discouraged by the negative account of Africa given by Sir Rider Haggard, was on the contrary, moved with pity and zeal to dare these dangers and barbarism in Africa to assist the "savage natives". According to the narrator.

Rev. Father Howard McGrace was an Irishman who having read Sir Rider Haggard's account of paganism and suffering in the dark continent had become smitten with pity for these poor souls and had quietly and persistently prayed to the Blessed Virgin Mary to help him develop the will to go over and help these primitive savages (78). 
It is significant to note that this man escaped from the problems of failed marriage to face yet a greater palaver of helping to salvage a primitive and peganistic people in Africa. His overall interest in coming to Africa was to serve, to spend time, and energy, to suffer and to improve the bad condition of the natives in the dark continent. He did exactly these but as fate would have it, he lost his life in active service in Africa. Even when the Rev. Father was provoked by the king of Igwulube, leading to what he described as "certain savage pride that these primitive people have about themselves" (136) his superior officer, Monsignor Shanahan advised him in these words:

In this vocation, patience is indispensable. Furthermore, you must always make allowances for the poor development of the people you will deal with. You are probably the first civilized man they have met... We must try to project love ad good will (136 137).

Though there are echoes of racial pride in the above statement, the truth remains that the Monisgnor understands the natives' predicaments and the need to apply caution, tolerance, understanding and love in dealing with Africans, if the developmental objectives of the Expatriates must be met. For example, he (the Monsignor) made his stand clearer when he further advised Father McGrace thus:

It is part of the reason why we must be patient and do our best to understand these people. Apart from the primary duty of upholding His Majesty's image as a man of peace, we have to by our conduct, create a climate conducive to trade and commerce for our traders, the Royal Niger Company. This last we will achieve by evangelizing them (138).

It is abundantly clear that the Expatriates major intentions in Africa in general and Igwulube in particular were to spread the gospel through evangelization and to trade with the natives. In each case, the natives benefited. The same was applicable to their roles in Umuaro and Okperi towns.

Through evangelization, the spiritual life of the people is elevated and through trade and commerce, the economic base of the people is enhanced. The overall result is the development of the people. And again, the Monsignor appreciated the fact that no meaningful progress or development could take place in the absence of peace, achieved by dialogue, tolerance, understanding and compromise. The novelist, by the above depiction of the motives of the Expatriates, portrays them in the positive image as agents of development and social order. A critical reader of The Year of the Locusts would profoundly appreciate the novelist's interest in the adventurous life of some Expatriates. And it is this spirit of adventure that propelled most of the Expatriates to come to Africa as merchants, missionaries, civil administrators and law enforcement agents in spite of the very frightening and repulsive report on Africa given by racist writers such as Rider Haggard's, Graham Greene, Joseph Conrad and James Joyce. For example, in the novel under review, Rev. Father McGrace is depicted as a very adventurous person who despite his reading of Rider Haggard negative report about Africa, decided to visit the continent to help the "poor souls."

\section{CONCLUSION}

From the panoramic journey through the novels used for the study, it is evident that colonialism is like a bitter pill coated with honey. The bitterness is diluted by the honey coverage. In like manner, while colonialism brought with it, cultural, historical and linguistic denigration of the colonial people, and enhanced economic exploitation of the colonies, it nevertheless brought positive incidental and accidental benefits to the colonies such as the building of schools, hospitals courts, government headquarters, and the acceptance of outcasts and the stoppage of the killing of twins in the colonies. It also boosted trade and commerce between the colonialists and the African colonial states.

\section{WORKS CITED}

Achebe, Chinua. Things Fall Apart. Ibadan: Heinemann, 1980.

--- Arrow of God. London: Heinemann, 1989.

--- Morning Yet on Creation Day. London: Heinemman, 1982.

Cary, Joyce. The African Witch. London: Longman, 1936.

--- Mr. Johnson. London: Longman, 1936.

Conrad, Joseph. Heart of Darkness and Other Stories. London: Wareheart, 1975.

Echeruo, Michael. Joyce Cary and the Novel of Africa. London: Longman, 1973.

Ezeifeh, Ifeanyi. The Year of the Locusts. Onitsha: Africana, 2007. 


\section{AUTHOR's BIOGRAPHY}

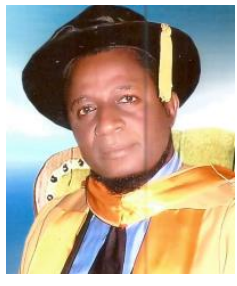

Dr. Echezona Ifejirika, is an Associate Professor of English Language, Chukwuemeka Odumegwu Ojukwu University Igbariam, Anambra State, Nigeria. $\mathrm{He}$ attended the University of Nigeria, Nsukka, University of Port-Harcourt and Nnamdi Azikiwe University, Awka, Nigeria. He holds the following degrees, BA (Ed), Med, MA and Ph.D in English Language.

He Bachelor of Arts (Hons.) degree in English/Education.

BA (Ed), Master's Degree in Sociology of Education (Med) Master's degree in English (MA) and Doctor of Philosophy in English (Ph.D).

He currently heads the Department of English Language of his University.

He has written many books in English language and literature in English. 